\title{
The use of functional magnetic resonance imaging in reducing a risk of postoperative neurological deficits in the patients with brain tumour
}

\section{Rola czynnościowego rezonansu magnetycznego w ograniczeniu pooperacyjnych deficytów neurologicznych u chorych na guzy mózgu}

Michał Tymowski', Krzysztof Majchrzak', Barbara Bobek-Billewicz², Piotr Ładziński', Henryk Maichrzak'

1 Klinika Neurochirurgii w Sosnowcu, Śląski Uniwersytet Medyczny w Katowicach

2Zakład Radiodiagnostyki, Instytut Onkologii w Gliwicach

Neurologia i Neurochirurgia Polska 2013; 47, 6: 547-554

DOI: 10.5114/ninp.2013.39072

\begin{abstract}
Background and purpose: The purpose of the study was to compare the results of operative treatment of tumours located in the sensory-motor cortex guided with functional magnetic resonance imaging (fMRI) combined with the neuronavigation system to the results of classical operative treatment. Material and methods: The studied group comprised $28 \mathrm{pa}-$ tients with a tumour located in the sensory-motor cortex area who underwent surgery guided with fMRI and the neuronavigation system. A control group comprised 30 patients with the same clinical diagnosis, operated on without functional neuronavigation.

Results: The use of functional neuronavigation allowed for an $18 \%$ reduction in the intensity of neurological deficits after surgical treatment in patients from the studied group, compared to the subjects from the control group $(p=0.0001)$. In the patients with diagnosed high-grade glioma, improvement in the neurological condition in the studied group was $16 \%$ $(p=0.03)$. The initial neurological condition and the results of surgical treatment in patients with a tumour located less than $5 \mathrm{~mm}$ from the sensory-motor cortex, determined in fMRI examination, are worse than in patients with a tumour located more than $5 \mathrm{~mm}$.

Conclusions: In patients with a diagnosed brain tumour in the sensory-motor cortex who have neurological deficits, fMRI
\end{abstract}

\section{Streszczenie}

Wstęp i cel pracy: Celem pracy było porównanie wyników leczenia chorych z guzami okolicy kory czuciowo-ruchowej operowanych przy użyciu czynnościowego rezonansu magnetycznego (fMRI) i neuronawigacji z wynikami uzyskanymi przed wprowadzeniem tych metod.

Materiał i metody: Grupa badana składała się z 28 chorych z guzem mózgu w okolicy kory czuciowo-ruchowej, których operowano z wykorzystaniem fMRI w połączeniu z systemem neuronawigacji. Grupę kontrolną stanowiło 30 chorych $\mathrm{z}$ analogicznym rozpoznaniem, operowanych bez użycia neuronawigacji czynnościowej.

Wyniki: Zastosowanie neuronawigacji czynnościowej pozwoliło na zmniejszenie o $18 \%$ częstości występowania deficytów neurologicznych pojawiających się po operacji w grupie badanej w porównaniu z chorymi z grupy kontrolnej $(p=0,0001)$. $\mathrm{W}$ grupie chorych z nisko zróżnicowanymi guzami pochodzenia glejowego wyniki pod względem pooperacyjnego stanu neurologicznego były lepsze o $16 \%(p=0,03)$. Wykazano także, że wyjściowy stan neurologiczny i wyniki leczenia operacyjnego są gorsze $\mathrm{u}$ chorych $\mathrm{z}$ guzem położonym $\mathrm{w}$ odległości mniejszej niż $5 \mathrm{~mm}$ od pola aktywności kory ruchowej wyznaczonej w fMRI.

Wnioski: Czynnościowy rezonans magnetyczny pozwala na uzyskanie klinicznie przydatnych obrazów pól aktywności

Correspondence address: dr med. Michał Tymowski, Katedra i Oddział Kliniczny Neurochirurgii, Plac Medyków 1, 41-200 Sosnowiec, Polska, e-mail: tymowski.michal@gmail.com

Received: 5.01.2012; accepted: 18.12.2012 
provides valuable imaging data on active areas. Tumour location of more than $5 \mathrm{~mm}$ from the fMRI active area of the sensory-motor cortex is connected with a considerably lower risk of postoperative neurological deficits. Removing a tumour in the sensory-motor cortex region, guided with fMRI and the neuronavigation system, considerably lowers the risk of postoperative development or exacerbation of neurological deficits.

Key words: brain tumours, surgical treatment, fMRI.

\section{Introduction}

Contemporary approach to the surgical treatment of brain tumours relates maximal radicality of resection with an effort to minimize permanent neurological deficits. This is particularly relevant for patients with glial tumours [1]. In order to achieve this effect, however, an intraoperative mapping of eloquent areas is essential. Direct cortical and white mater stimulation is considered a golden standard in surgical repertoire [2]. On the other hand, recent developments in highly specialized imaging studies, functional in particular, facilitated vast expansion of neuronavigation system applications $[3,4]$. The role of functional magnetic resonance imaging (fMRI) in risk assessment and preoperative planning along with intraoperative localization of eloquent areas has been a subject of numerous reports [1-3,5].

The aim of our study was to compare the surgical outcomes of patients with tumours located within the sensory-motor cortex who underwent fMRI-guided surgery with neuronavigation to the results of operative treatment without preoperative eloquent areas' mapping.

\section{Material and methods}

Our cohort included 58 patients who underwent surgery for sensory-motor cortex tumours at the Department of Neurosurgery of the Silesian Medical University in Sosnowiec. Studied group included 28 patients ( 16 women and 12 men, mean age 42.2 years), who were operated on with fMRI-guided neuronavigation between 2007 and 2008. Mean time from the first symptoms of the disease to the surgery averaged 29.8 weeks. Control group consisted of 30 patients with analogous clinical diagnosis who had their surgery between 2004 and 2006 without functional neuronavigation. In order to select the control group, we initially performed an analysis of 120 patients with tumour localized within fronto-parietal region who were operated on by the same u pacjentów z guzami w okolicy kory czuciowo-ruchowej mózgu. Lokalizacja guza w odległości ponad $5 \mathrm{~mm}$ od pola aktywności wiąże się ze zmniejszeniem ryzyka wystąienia pooperacyjnych deficytów neurologicznych. Zastosowanie neuronawigacji z fMRI w znaczący sposób zmniejsza ryzyko wystąpienia lub nasilenia się w okresie pooperacyjnym deficytów neurologicznych.

Słowa kluczowe: guz mózgu, leczenie chirurgiczne, fMRI.

team of surgeons as the studied group. Patients whose clinical status or perioperative course could influence postoperative neurological evaluation (i.e. patients with multiple neoplastic lesions within CNS, patients with vascular cerebral diseases or those with postoperative haematomas) were excluded from the study. Eventually, we selected 77 patients, and then 15 men and 15 women were chosen randomly from that cohort. Mean age of the group was 47.8 years and the duration of the disease averaged 23.5 weeks. No significant differences between groups with respect to sex $(p=0.69)$ or age distribution $(p=0.12)$ were found.

Neurological status, with particular attention to motor deficits on admission, discharge and on the first postoperative control a month after surgery was evaluated. No further evaluation of the neurological status was performed due to the fact that a significant fraction of the patients had postoperative radiotherapy that might influence clinical status of the patient. In order to evaluate neurological status of the patients, a special scale for evaluation of motor deficits was created (SDR-110). In this scale, one subtracts the number of points relevant for a given degree of motor deficits from the initial value of 110 pts. Whenever the degree of paresis was assessed between specific points in Lovett scale, a lower value was selected. Clinical symptoms of accessory motor area injury on top of limbs' motor deficits encompass a specific type of apraxia called 'speech arrest'. For this reason, a postoperative neurological examination included evaluation of possible speech deficits. Patients with SDR-110 grading at maximum were recognized as a very good neurological status. 100-80 pts in SDR-110 scale suggested moderate neurological deficits. A poor neurological condition was assigned to patients who scored below 70 pts (Table 1).

Preoperative workup for patients in the studied group included imaging studies in the Department of Radiodiagnostics of the Institute of Oncology, the Gliwice Branch. All of the patients received detailed infor- 
mation on type and purpose of the proposed studies and gave informed consent. The day before examination, the patients received the plan of motor exercises to be performed during examination in order to rehearse. Imaging studies were usually performed 2 days prior to surgery on 1.5 T Siemens Avanto scanner with 8-channel matrix head coil. Patient's head was positioned with elastic belts and padding within the coil in order to minimize its mobility. Functional images were acquired with BOLD (Blood Oxygenation Level Dependent) sequence (single-shot multislice $\mathrm{T} 2 *$-weighted gradient echo EPI sequence with TR/TE/FA: 3580/50/90, $3 \mathrm{~mm}$ slice thickness, $220 \times 220 \mathrm{FOV}$ and $64 \times 64$ matrix) that covered the whole cerebrum. Whole study was performed according to a block methodology a block of activity and block of rest with $36 \mathrm{~s}$ duration of a given block. BOLD sequences lasted $290 \mathrm{~s}$ and encompassed 4 blocks of activity and 4 blocks of rest. Motor cortex stimulation was achieved with confronting finger movements and feet flexion and extension. In order to delineate motor and sensory speech areas, word generation and association methodology was implemented. Movement artifacts were automatically eliminated with proprietary manufacturer software provided with MRI scanner. During the same session, T1- and T2-weighted isotropic 3D and FLAIR sequences were acquired as well. Then PatXfer software was used to transfer all imaging data into Vector $\mathrm{Vision}^{2}$ neuronavigation planning workstation (BrainLab AG, Munich, Germany). Preoperative planning was performed with BrainLab iPlan Cranial 2.6 software based on morphological and functional MRI data. iPlan Cranial 2.6 software employs a general linear model in order to define motor activity area based on statistical parametric mapping. The changes of statistical threshold for the signal course are used for the creation of active area images that are defined by the level of statistical significance. The higher the threshold, the stronger the probability for accurate active area delineation. However, increased probability values render smaller area of a given active zone. Accordingly, each patient had an individually defined statistical threshold value. Still, no threshold value was set at the level that would ensure statistical significance of the result higher than $p=0.001$. An important part of the planning was to establish the relationship between tumour location and fMRI-defined primary sensory-motor active field. Low-grade gliomas margins were delineated based on FLAIR sequence MR images while high-grade gliomas or metastatic tumours margins were defined based on T1-weighted MR images with contrast in order
Table 1. Point grading according to motor deficit scale (SDR-110)

\begin{tabular}{|lcc|}
\hline $\begin{array}{l}\text { Upper extremity } \\
\text { paresis (Lovett } \\
\text { scale grading) }\end{array}$ & $\begin{array}{c}\text { Lower extremity } \\
\text { paresis (Lovett } \\
\text { scale grading) }\end{array}$ & $\begin{array}{c}\text { Speech } \\
\text { disturbances }\end{array}$ \\
\hline V grade $=0$ pts & V grade $=0$ pts & Absent $=0$ pts \\
\hline IV grade $=-10$ pts & IV grade $=-10$ pts & Present $=-10$ ts \\
\hline III grade $=-20$ pts & III grade $=-20$ pts & \\
\hline II grade $=-30$ pts & II grade $=-30$ pts & \\
\hline I grade $=-40$ pts & I grade $=-40$ pts & \\
\hline 0 grade $=-50$ pts & 0 grade $=-50$ pts & \\
\hline
\end{tabular}

to do so. Next, the size of craniotomy, trajectory and safe location for corticotomy as well as an extent of planned resection were defined.

During surgery, patient's head had initially been fixed in a head holder so as to direct gravitational force in one plane and thus facilitate eventual corrections whenever a brain shift occurred. In one patient head was rotated by $90^{\circ}$; all other cases heads were placed at $0^{\circ}$ so as to ensure the trajectory at $90^{\circ}$ relative to the axial plane. Additionally, in order to diminish the risk of navigational error related to the brain shift, we limited the use of antiedema medications, the size of craniotomy and avoided the opening of subarachnoid space prior to initial navigational measurements. Upon dural opening and prior to tumour resection, the locations of cortical, fMRI-active areas were identified with neuronavigation in relation to the tumour location. In patients whose fMRI studies showed motor cortex active areas immediately adjacent to the tumour, a $5-\mathrm{mm}$ borderline margin was delineated that limited the extent of resection to incomplete.

In every case where tumour was separated from active motor area by a sulcus, the extent of the resection was limited by the arachnoid of the pathologically changed gyrus. On top of that, the accuracy of neuronavigational indications was verified through control tracing of anatomical landmarks on the brain surface such as large veins that were marked on a planning workstation as a part of venous map. Tumour resection was initialized distally from the delineated motor active area. During resection, a special care was given to avoid the 'undermining' of the delineated motor area, coagulation adjacent to sensory-motor cortex or brain spatulas placement. Supplemental motor area or pre-motor area did not limit the tumour resection even in cases when they showed signs of activation on fMRI.

Localization of fMRI-active areas on the cortex was performed at the beginning of the surgery, upon dural 
opening. Patients from the control group underwent classical craniotomy without functional neuronavigation. Statistical analysis of the data was performed with Statistica 5.5 software.

\section{Results}

None of the patients in the studied group showed any complications during or after fMRI study. We managed to find a diagnostically valid image of active areas of the motor cortex in all cases. Moreover, during surgery none of the patients from the studied group upon identification of fMRI-active motor areas presented any significant brain shift that could hinder identification of anatomical and functional structures marked during planning.

Neurological status of 17 patients from the studied group was very good on admission. Nine patients presented with moderate neurological deficits and were assessed at 80 to 100 pts according to SDR-110 scale. Two patients in the worst neurological condition scored 70 pts on admission. On discharge, neurological status of 13 patients deteriorated, in 14 remained stable and 1 patient improved when compared to preoperative examinations. A month after surgery, neurological condition of 12 patients improved while the remaining 16 remained stable. None of the patients showed any signs of neurological deterioration. Nineteen patients scored 110 pts; 15 of them were initially in a very good condition and another 4 patients improved when compared to their preoperative neurological condition.

Eighteen patients in the control group showed no neurological deficits, 9 presented with moderate neurological deficits and 3 in a poor neurological condition. On discharge, however, 22 patients in the control group deteriorated, 7 remained stable and 1 improved when compared to their preoperative status. At follow up, neu- rological status of 17 patients improved and 13 patients remained stable when compared to neurological condition at discharge. Five patients scored 110 pts. Importantly, all of the patients who scored 110 pts a month after discharge were initially in a very good neurological status (Table 2).

In the studied group, 13 patients were diagnosed with high-grade glioma (46.4\%), 12 with a low-grade gliomas and 3 with metastatic tumour. In the control group, on the other hand, 22 patients had high-grade gliomas (73.3\%), 2 - low-grade gliomas and 7 metastatic tumours. A percentage of high-grade gliomas varied significantly between groups $\left(p<0.03, \chi^{2}\right.$ test).

No other statistically significant differences were found between studied and control groups related to histopathological diagnosis. Given a significant preponderance of high-grade gliomas in the control group we elected to compare neurological status of patients from studied and control groups after surgery with this particular diagnosis as presented in the Table 3 .

Krishan et al. [5] and Peraud et al. [6] showed that surgical outcome is worse in tumours located less than $5 \mathrm{~mm}$ from primary motor cortex area. Moreover, Pierrot et al. [7] pointed out that the difference between fMRI-active motor cortex areas locations and sensorymotor cortex locations confirmed intraoperatively by direct cortical stimulation is significant and averages $3.8 \mathrm{~mm}$ [7]. Accordingly, we elected to divide studied group into two subgroups based on the distance from the tumour to the fMRI-active motor area location. Group I consisted of 15 patients with tumours located less than $5 \mathrm{~mm}$ from motor active area. Group II encompassed 13 patients with tumours located at least $5 \mathrm{~mm}$ from it. Neurological status of the patients from both groups evaluated at given time points can be found in Table 4.

Table 2. Neurological status of the patients from studied and control groups in subsequent follow-up examinations, based on point grading according to motor deficit scale SDR-110

\begin{tabular}{|c|c|c|c|c|c|c|}
\hline \multirow[t]{2}{*}{ Examination } & \multirow[t]{2}{*}{ Group } & \multicolumn{4}{|c|}{ SDR-110 } & \multirow{2}{*}{$\begin{array}{c}P \text {-value } \\
\text { (Mann-Whitney U test) }\end{array}$} \\
\hline & & Mean & Standard deviation & Median & Range & \\
\hline \multirow[t]{2}{*}{1} & Studied & 102.1 & 12.6 & 110 & $70-110$ & \multirow[t]{2}{*}{0.91} \\
\hline & Control & 100.7 & 16.4 & 110 & $40-110$ & \\
\hline \multirow[t]{2}{*}{2} & Studied & 86.4 & 28.6 & 100 & $20-110$ & \multirow[t]{2}{*}{0.01} \\
\hline & Control & 69.0 & 25.9 & 70 & $30-110$ & \\
\hline \multirow[t]{2}{*}{3} & Studied & 101.4 & 15.1 & 110 & $60-110$ & \multirow[t]{2}{*}{0.0001} \\
\hline & Control & 82.0 & 20.9 & 80 & $40-110$ & \\
\hline
\end{tabular}


Table 3. Neurological status of the patients with high-grade gliomas, according to motor deficit scale SDR-110

\begin{tabular}{|c|c|c|c|c|c|c|}
\hline \multirow[t]{2}{*}{ Examination } & \multirow[t]{2}{*}{ Group } & \multicolumn{4}{|c|}{ SDR-110 } & \multirow{2}{*}{$\begin{array}{c}\text { P-value } \\
\text { (Mann-Whitney U test) }\end{array}$} \\
\hline & & Mean & Standard deviation & Median & Range & \\
\hline \multirow[t]{2}{*}{1} & Studied & 99.2 & 17.1 & 110 & $70-110$ & 0.76 \\
\hline & Control & 99.5 & 17.3 & 110 & $40-110$ & \\
\hline \multirow[t]{2}{*}{2} & Studied & 93.8 & 20.2 & 100 & $50-110$ & 0.002 \\
\hline & Control & 65.9 & 23.2 & 65 & $30-110$ & \\
\hline \multirow[t]{2}{*}{3} & Studied & 97.7 & 19.6 & 110 & $60-110$ & 0.03 \\
\hline & Control & 81.8 & 19.2 & 80 & $40-110$ & \\
\hline
\end{tabular}

Table 4. Neurological status of the patients depending on the distance from active motor area to the tumour margin, according to motor deficit scale SDR-110

\begin{tabular}{|c|c|c|c|c|c|c|}
\hline \multirow[t]{2}{*}{ Examination } & \multirow[t]{2}{*}{ Distance } & \multicolumn{4}{|c|}{ SDR-110 } & \multirow{2}{*}{$\begin{array}{c}\text { P-value } \\
\text { (Mann-Whitney U test) }\end{array}$} \\
\hline & & Mean & Standard deviation & Median & Range & \\
\hline \multirow[t]{2}{*}{1} & $<5 \mathrm{~mm}$ & 98.0 & 14.2 & 100 & $70-110$ & \multirow[t]{2}{*}{0.05} \\
\hline & $>5 \mathrm{~mm}$ & 106.9 & 8.5 & 110 & $80-110$ & \\
\hline \multirow[t]{2}{*}{2} & $<5 \mathrm{~mm}$ & 72.0 & 31.2 & 70 & $20-100$ & \multirow[t]{2}{*}{0.003} \\
\hline & $>5 \mathrm{~mm}$ & 103.1 & 11.8 & 110 & $80-110$ & \\
\hline \multirow[t]{2}{*}{3} & $<5 \mathrm{~mm}$ & 96.0 & 17.6 & 100 & $60-110$ & \multirow[t]{2}{*}{0.04} \\
\hline & $>5 \mathrm{~mm}$ & 107.7 & 8.3 & 110 & $80-110$ & \\
\hline
\end{tabular}

\section{Discussion}

Any surgical treatment for a brain tumour should result in a maximum safe resection on one hand and the preservation of the best neurological status possible on the other [8-13]. A contemporary 'golden standard' in the surgical treatment of tumours localized within eloquent areas involves cortical mapping with direct intraoperative stimulation [14-18]. Regardless of its numerous advantages, this method has certain limitations, the most important one being the lack of preoperative options to localize eloquent areas of the cortex relative to the tumour. It impedes preoperative planning along with the risk assessment of potential, surgery-related neurological deficits [7,14-21]. On the other hand, modern functional imaging techniques, including fMRI, meet these expectations. The advantages of fMRI include non-invasiveness, reproducibility and capability to combine high-resolution structural MRI images suitable for neuronavigation with functional studies in one session [21-29]. In contrast to PET and SPECT, fMRI does not expose patients to radiopharmaceuticals and ensures superior spatial resolution [22-26]. During fMRI studies, however, patient's cooperation, prop- er selection of activation tasks and statistical analysis plays a crucial role [30-35].

Lack of proper patient's cooperation usually results in head's movements during imaging [35] while data acquisition procedure for $\mathrm{fMRI}$ activation imaging is extremely sensitive even to minimal head movements. Lehericy et al. [35] in their study proved that head movements rendered impossible a proper imaging of the activation of a primary motor area in $5 \%$ of patients. The difficulties with motor task performance related to neurological deficits or qualitative consciousness disturbances are the most usual source of head movements [35]. None of the patients in our cohort, however, hampered interpretation of fMRI results by head movements. This might arise from their good neurological status preoperatively. Only two patients had neurological deficits that corresponded to 70 pts according to SDR-110 scale, still we were able to acquire good quality primary motor cortex area activation images without motor artifacts related to head movements. Moreover, minor head movements might be corrected with a proper software application. Holodny et al. [36] reported a case of 40-year-old patient with a large, high-grade glioma of the right hemisphere in which they acquired 
no images of motor cortex activation area despite of the fact that patient preserved functional movements of left extremities. The authors explained this phenomenon by a disruption of cerebral circulation autoregulation within the tumour that, in turn, makes fMRI imaging unfeasible. Glial tumours localized within motor cortex might cause another problem related to the possibility that primary motor cortex activation area might localize within the tumour. Schiffbauer et al. [37] proved the possibility of motor activation areas localization within neoplastic brain. We have also found this phenomenon in a subgroup of patients who underwent fMRI examination; one of our patients, 57-year-old female with glioblastoma located in right fronto-parietal region showed fMRI-active motor area partially overlaid on the tumour. Her neurological exam on admission scored at 70 pts. During preoperative planning, we elected to perform a partial resection of the tumour. During surgery, we traced a $5-\mathrm{mm}$ margin on the border of $\mathrm{fMRI}$-active area based on functional neuronavigation and performed partial resection of the tumour. Immediately after surgery her left sided hemiparesis deteriorated; on discharge she was assessed at 50 pts. A month later patient returned to her initial values.

Another phenomenon, which arises from diseaserelated interhemispheric functional reorganisation involves the coexistence of functional activity areas in both hemispheres for one extremity $[34,38]$. Ulmeri et al. [38] reported homotopic reorganisation of the cerebral cortex in $27 \%$ of patients with tumours localized closer than $5 \mathrm{~mm}$ from motor cortical activity area.

During surgery, several measures were implemented in order to reduce the risk of brain shift that would impair the ability to perform reliable measurements with neuronavigation system. Unless intraoperative methods that ensure accuracy of neuronavigational measurements are available, it is of value to use anatomical landmarks as a reference. Whenever one navigates the surface of cerebral cortex, we found it very useful to create a preoperative map of venous system in the vicinity of the tumour location. Superficial veins shift along with the adjacent cerebral cortex thus facilitating measurement accuracy verification.

Krishan et al. [5] presented surgical outcomes of 52 patients operated on with fMRI-based functional neuronavigation. They showed in their study that $35 \%$ of patients with tumours localized less than $5 \mathrm{~mm}$ from active motor areas delineated during fMRI study suffered a permanent neurological deterioration after sur gery. Likewise, 6 (40\%) of patients in our cohort whose tumours were localized less than $5 \mathrm{~mm}$ from active motor area showed neurological deterioration in control examination. In 5 cases, neurological deterioration was assessed at 10 pts, only 1 patient deteriorated by 30 pts according to SDR-110 scale. On the other hand, patients in our studied group who underwent surgery for tumours located further than $5 \mathrm{~mm}$ from active motor area remained stable on their follow up neurlogical examination; one of them even improved when compared to preoperative neurological condition. Furthermore, initial neurological condition of patients with tumours located closer than $5 \mathrm{~mm}$ from active motor areas was significantly worse when compared to those with tumours located further than $5 \mathrm{~mm}$. On discharge, an average neurological status of the patients from group I was worse by $30 \%$ from analogous results for patients in the group II. Only 2 patients in the group I were in the very good neurological condition while in the group II 9 patients scored 110 pts. A follow up examination a month after discharge revealed that patients from the group II were in better condition than on admission and averaged $11 \%$ above an average neurological status for the patients in the group I. Despite of the fact that neurological status of the patients on discharge significantly deteriorated when compared to initial values in the follow up examination average score in SDR-110 scale almost returned to the inintial values. It suggests preservation of primary motor cortex adjacent to the tumour. Our results allowed us to conclude that tumour located less than $5 \mathrm{~mm}$ from fMRI-active motor cortex area results in worse neurological status of the patient on admittion. These patients are at higher risk of new or exacerbation of preexisting neurological deficits immediately after surgery as well as in a later follow up. Moreover, tumour location this close to the motor cortex has a negative influence on the extent of resection that might be performed without a significant risk of permanent neurological deficits $[5,6,39]$. Accordingly, tumour location closer than $5 \mathrm{~mm}$ from primary motor cortex area affects prognosis and quality of life of patients after surgery afecting the extent of possible resection and rendering a higher risk of neurological deficits exacerbation [8-13]. It was considered safe to operate on patients whose tumours are localized further than $10 \mathrm{~mm}$ from fMRI defined motor activity area $[5,6]$. In order to perform full evaluation of fMRI-based neuronavigation, we compared surgical outcomes of patients in the studied group with those who underwent classic surgery.

Neurological status of patients from both groups did not differ on admission $(p=0.91)$. Neurological con- 
dition of patients in the studied group was significantly better on discharge and during follow up. Implementation of functional neuronavigation facilitated $18 \%$ reduction of neurological deficits' incidence on follow up examination performed a month after discharge when compared to the control group.

Histopathological diagnoses' review revealed higher number of high-grade gliomas in control group. Hence, we decide to evaluate surgical outcomes in relation to histopathology owing to the known difference in the growth patterns between low and high-grade gliomas. In both groups patients with high-grade gliomas presented in a slightly worse neurological condition when compared to the whole group. Functional MRI-based functional neuronavigation allowed to achive better neurological outcomes in over $16 \%$ of patients in the studied group when compared to the controls.

\section{Conclusions}

1. Tumour location relative to the active motor area of the cerebral cortex plays a crucial role for surgery planning and risk assessment of new or exacerbated neurological deficits. Our study proved that tumour location further than $5 \mathrm{~mm}$ from active area is associated with significantly lower risk of neurological deficits.

2. Based on performed analyses, we showed that sensory-motor cortex tumour resection with $\mathrm{fMRI-based}$ neuronavigation significantly reduces the risk of new or exacerbated neurological deficits after surgery.

\section{Disclosure}

Authors report no conflict of interest.

\section{References}

1. Majchrzak K., Kaspera W., Bobek-Billewicz B., et al. The assessment of prognostic factors in surgical treatment of low-grade gliomas: a prospective study. Clin Neurol Neurosurg 2012; 114: 1135-1144.

2. Majchrzak K., Bobek-Billewicz B., Tymowski M., et al. Surgical treatment of insular tumours with tractography, functional magnetic resonance imaging, transcranial electrical stimulation and direct subcortical stimulation support. Neurol Neurochir Pol 2011; 45: 351-362.

3. Petrella J.R., Shah L.M., Harris K.M., et al. Preoperative functional MR imaging localization of language and motor area: effect on therapeutic decision making in patients with potentially resectable brain tumors. Radiology 2006; 240: 793-802.
4. Fersten E., Jakuciński M., Kuliński R., et al. Neuropsychological assessment of language functions during functional magnetic resonance imaging: development of new tasks. Preliminary report. Neurol Neurochir Pol 2011; 45: 567-576.

5. Krishnan R., Raabe A., Hattingen E., et al. Functional magnetic resonance imaging-integrated neuronavigation: correlation between lesion-to-motor cortex distance and outcome. Neurosurgery 2004; 55: 904-915.

6. Peraud A., Meschede M., Eisner W., et al. Surgical resection of grade II astrocytomas in the superior frontal gyrus. Neurosurgery 2002; 50: 966-977.

7. Pirotte B., Voordecker P., Neugroschl C., et al. Combination of functional magnetic resonance imaging-guided neuronavigation and intraoperative cortical brain mapping improves targeting of motor cortex stimulation in neuropathic pain. Neurosurgery 2005; 56 (Suppl 2): 344-359.

8. Philippon J.H., Clemenceau S.H., Fauchon F.H., et al. Supratentorial low-grade astrocytomas in adults. Neurosurgery 1993; 32: 554-559.

9. Laws E.R. Jr., Taylor W.F., Clifton M.B., et al. Neurosurgical management of low-grade astrocytoma of the cerebral hemispheres. J Neurosurg 1984; 61: 665-673.

10. Piepmeier J., Christopher S., Spencer D., et al. Variations in the natural history and survival of patients with supratentorial lowgrade astrocytomas. Neurosurgery 1996; 38: 872-879.

11. Vertosick F.T., Selker R.G., Arena V.C. Survival of patients with well-differentiated astrocytomas diagnosed in the era of computed tomography. Neurosurgery 1991; 28: 496-501.

12. Brown P.D., Maurer M.J., Rummans T.A., et al. A prospective study of quality of life in adults with newly diagnosed high-grade gliomas: the impact of the extent of resection on quality of life and survival. Neurosurgery 2005; 57: 495-504.

13. Barker F.G., Chang S.M., Gutin P.H., et al. Survival and functional status after resection of recurrent glioblastoma multiforme. Neurosurgery 1998; 42: 709-720.

14. Cedzich C., Pechstein U., Schramm J., et al. Electrophysiological considerations regarding electrical stimulation of motor cortex and brain stem in humans. Neurosurgery 1998; 42: 527-532.

15. Walker J., Quiñones-Hinojosa A., Berger M.S. Intraoperative speech mapping in 17 bilingual patients undergoing resection of a mass lesion. Neurosurgery 2004; 54: 113-118.

16. Duffau H., Capelle L., Sichez J., et al. Intra-operative direct electrical stimulations of the central nervous system. The Salpêtrière experience with 60 patients. Acta Neurochir (Wien) 1999; 141: 1157-1167.

17. Duffau H., Capelle L., Sichez N., et al. Intraoperative mapping of the subcortical language pathways using direct stimulation. Brain 2002; 125: 199-214.

18. Haglund M., Berger M.S., Shamseldin M., et al. Cortical localization of temporal lobe language sites in patients with gliomas. Neurosurgery 1994; 34: 567-576.

19. Cedzich C., Taniguchi M., Schäfer S., et al. Somatosensory evoked potential phase reversal and direct motor cortex stimulation during surgery in and around the central region. Neurosurgery 1996; 38: 962-970.

20. Tai Y.F., Piccini P. Applications of positron emission tomography (PET) in neurology. J Neurol Neurosurg Psychiatry 2004; 75: 669-676. 
21. Wunderlich G., Knorr U., Herzog H., et al. Precentral glioma location determines the displacement of cortical hand representation. Neurosurgery 1998; 42: 18-27.

22. Levivier M., Goldman S., Bidaut L., et al. Positron emission tomography-guided stereotactic brain biopsy. Neurosurgery 1992; 31: 792-797.

23. Braun V., Dempf S., Tomczak R., et al. Multimodal cranial neuronavigation: direct integration of functional magnetic resonance imaging and positron emission tomography data: technical note. Neurosurgery 2001; 48: 1178-1182.

24. Rachinger W., Goetz C., Pöpperl G., et al. Positron emission tomography with O- $\left(2-\left[{ }^{18} \mathrm{~F}\right]\right.$ fluoroethyl)-l-tyrosine versus magnetic resonance imaging in the diagnosis of recurrent gliomas. Neurosurgery 2005; 57: 505-511.

25. Pirotte B., Goldman S., Van Bogaert P., et al. Integration of $\left[{ }^{11} \mathrm{C}\right]$ methionine-positron emission tomographic and magnetic resonance imaging for image-guided surgical resection of infiltrative low-grade brain tumors in children. Neurosurgery 2005; 57 (Suppl 1): 128-139.

26. Kamada K., Takeuchi F., Kuriki S., et al. Functional neurosurgical simulation with brain surface magnetic resonance images and magnetoencephalography. Neurosurgery 1993; 33: 269-273.

27. Rezai A., Hund M., Kronberg E., et al. The interactive use of magnetoencephalography in stereotactic image-guided neurosurgery. Neurosurgery 1996; 39: 92-102.

28. Nimsky C., Ganslandt O., Kober H., et al. Integration of functional magnetic resonance imaging supported by magnetoencephalography in functional neuronavigation. Neurosurgery 1999; 44: 1249-1256.

29. Hund M., Rezai A.R., Kronberg E., et al. Magnetoencephalographic mapping: basis of a new functional risk profile in the selection of patients with cortical brain lesions. Neurosurgery 1997; 40: 936-943.

30. Roux F.E., Ibarrola D., Tremoulet M. Methodological and technical issues for integrating functional magnetic resonance imaging data in a neuronavigational system. Neurosurgery 2001; 49: 1145-1157.

31. Hirsch J., Ruge M.I., Kim K.H., et al. An integrated functional magnetic resonance imaging procedure for preoperative mapping of cortical areas associated with tactile, motor, language, and visual functions. Neurosurgery 2000; 47: 711-722.

32. Rutten G.J., Ramsey N.F., van Rijen P.C., et al. FMRI-determined language lateralization in patients with unilateral or mixed language dominance according to Wada test. Neuroimage 2002; 17: 447-460.

33. Yetkin F.Z., Mueller W.M., Morris G.L., et al. Functional MR activation correlated with intraoperative cortical mapping. AJNR Am J Neuroradiol 1997; 18: 1311-1315.

34. Vikingstad E.M., Cao Y., Thomas A., et al. Language hemispheric dominance in patients with congenital lesions of eloquent brain. Neurosurgery 2000; 47: 562-570.

35. Lehericy S., Duffau H., Cornu P., et al. Correspondence between functional magnetic resonance imaging somatotopy and individual brain anatomy of the central region: comparison with intraoperative stimulation in patients with brain tumors. J Neurosurg 2000; 92: 589-598.
36. Holodny A.I., Schulder M., Liu W.C., et al. Decreased BOLD functional MR activation of the motor and sensory cortices adjacent to a glioblastoma multiforme: implications for image-guided neurosurgery. AJNR Am J Neuroradiol 1999; 20: 609-612.

37. Schiffbauer H., Ferrari P., Rowley H., et al. Functional activity within brain tumors: a magnetic source imaging study. Neurosurgery 2001; 49: 1313-1321.

38. Ulmer J.L., Hacein-Bey L., Mathews V.P., et al. Lesion-induced pseudo-dominance at functional magnetic resonance imaging: implications for preoperative assessments. Neurosurgery 2004; 55: 569-579.

39. Håberg A., Kvistad K., Unsgård G., et al. Preoperative blood oxygen level-dependent functional magnetic resonance imaging in patients with primary brain tumors: clinical application and outcome. Neurosurgery 2004; 54: 902-915. 